\title{
Salt water intrusion in the breakthrough valley of the river Aa between the Flemish coastal plain and the Saint Omer basin (France)
}

\author{
Luc Lebbe ${ }^{1}$, Devlin Depret ${ }^{2}$, Jasper Claus $^{3}$ and Gert Jan Devriese ${ }^{4}$ \\ ${ }^{1}$ Department of Geology Ghent University, Ghent, Belgium \\ ${ }^{2}$ G. Smeyers N.V., Zandhoven, Belgium \\ ${ }^{3}$ International Marine \& Dredging Consultants (IMDC), Antwerp, Belgium \\ ${ }^{4}$ Pidpa, Antwerp, Belgium
}

\begin{abstract}
The salinity distribution in a breakthrough valley has been studied based on field observations and using a numerical model. The studied valley is located in Northern France between the Saint Omer basin and the Flemish coastal plain. The field campaign starts with the installation of observation wells. In these observations wells the electrical conductivity is logged versus depth with an electro-magnetic device. These wells also allow the necessary measurements to deduce the fresh water heads. Some of the wells are used for the performance of a pumping test. The lateral variation of the electrical conductivity of the water in the drainage canals is measured. With a numerical model the evolution of the flow and distribution of the fresh and salt water are simulated. Two simulations are made with the same schematization of the groundwater reservoir consisting of quaternary marine sediments, silt and clay and with the same hydraulic and solute parameters and boundary conditions but with two different initial salinity distributions. The results of both simulations show that the salinity distribution in the quaternary marine sediments depends not only on the lateral variation of the watertable but also on the shape of the incision of the palaeovalley into the clay of Ypresian age. The salinity distribution in the lower part of the quaternary marine sediments depends first and foremost on the shape of the incision of the palaeo-valley into the clay of Ypresian age whereas the salinity distribution in the upper part of the quaternary marine sediments depends first and foremost on the lateral variation of the watertable.
\end{abstract}

\section{INTRODUCTION}

On the edges of coastal plains, and even beyond, salt water intrusions can occur in valleys which are surrounded or flanked by hills. An example of such an area is the Saint Omer basin and its connection to the Flemish coastal plain (Figure 1). The Saint Omer basin is a small subsiding basin where the river Aa rises at its southern edge and flows in the northwestern direction through the basin and in northern direction through the breakthrough valley into the Flemish coastal plain. The breakthrough valley is incised in the clay of Ypresian age (YC) and is filled with quaternary marine sediments (QMS). The valley is flanked by hills where the $\mathrm{YC}$ is covered with quaternary continental silt (QCS). The QMS are filled with salt, brackish and fresh water. The flow and the salinity distribution are studied by the aid of a numerical model which is verified and supported by field observations and tests. 


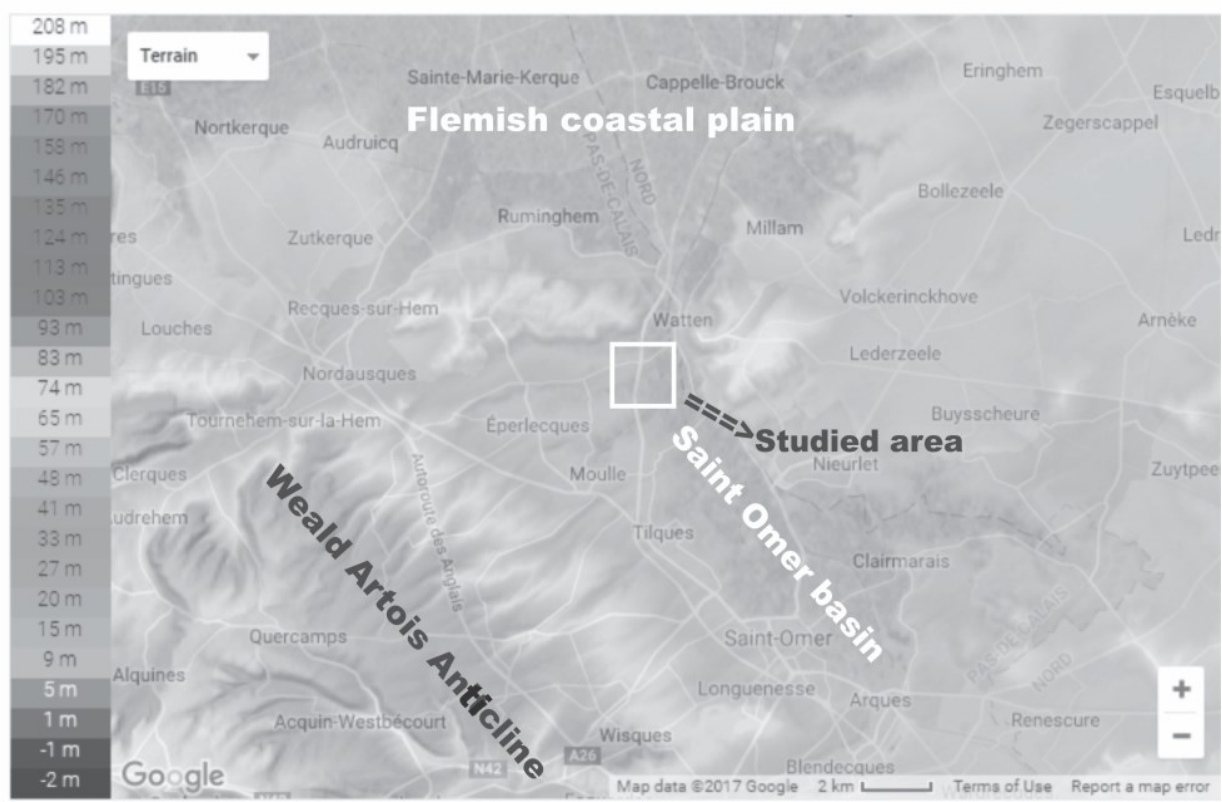

Figure 1. Topographic map with indication of the studied area and geological areas.

\section{D MODELLING}

The field work starts with the installation of a number of observation wells. The observations wells allow the measurements of fresh water head, the loggings of electrical conductivities of the depositions around the wells with an electro-magnetic device and the performance of a pumping test. In Figure 2 the lithostratigraphic cross section is shown along with electrical conductivity (EC) measured with the EM39-device. At the pumping test site a $3 \mathrm{~m}$ thick peat layer occurs. Above the peat there is a sequence from top to bottom of clay, silt, peat, sand and silt in which the electrical conductivity gradually increases with depth. The EC of the sediments reaches a maximum value of $380 \mathrm{mS} / \mathrm{m}$ in the lower two meter of the peat. Below the peat occurs a thick sand layer in which the screen of the pumped well PP is placed. The EC of the sand varies around $280 \mathrm{mS} / \mathrm{m}$. With the pumping test three hydraulic parameters are identified: the horizontal conductivity and specific elastic storage of the sand and the hydraulic resistance of the peat layer.

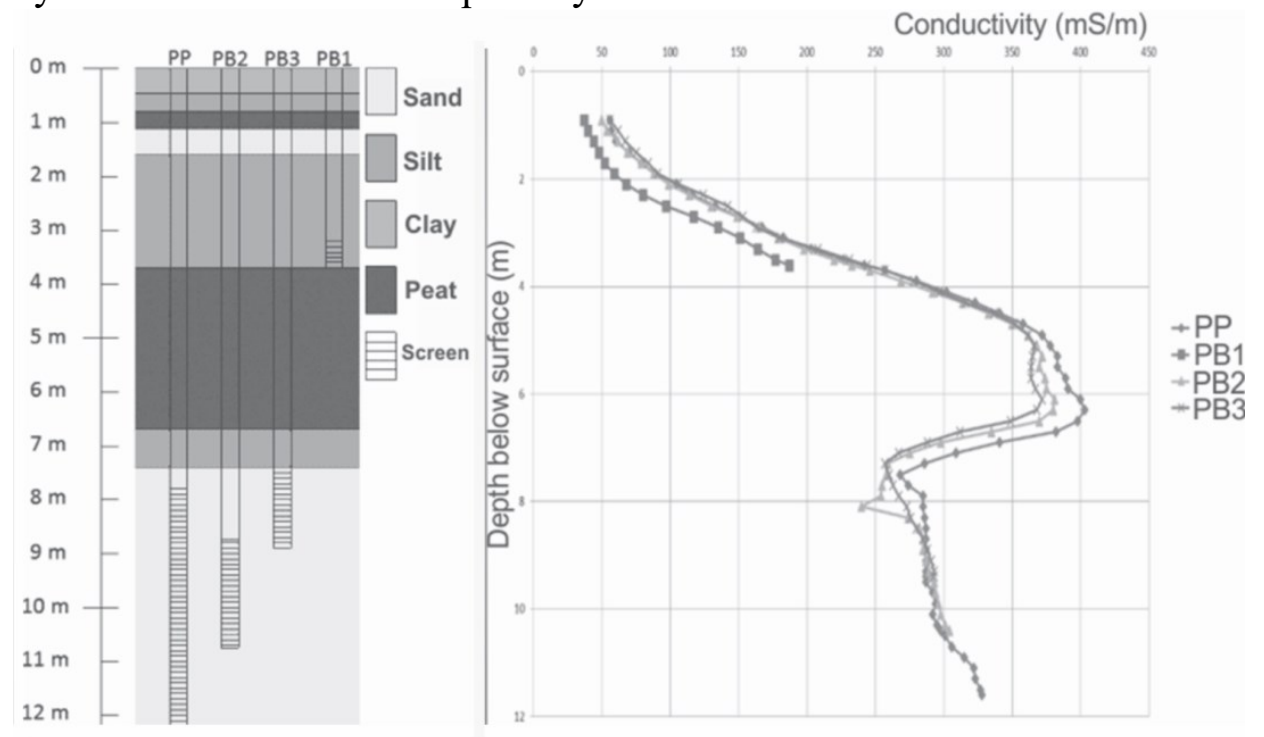

Figure 2. Lithostratigraphic cross section at the site of the pumping test along with the EM39 measurements in the wells of the pumping test PP, PB2, PB3 and PB1. 
In the central part of the studied area the lateral EC variation of the water in the drainage canals is measured on 22 October 2014. From these measurements the total dissolved solids (TDS) are derived. The TDS values vary between $300 \mathrm{mg} / \mathrm{l}$ and $5 \mathrm{~g} / \mathrm{l}$. The water in the drainage canals in the north western corner of the measured area has a TDS larger than $2 \mathrm{~g} / 1$.

\section{D MODELLING}

The MOCDENS3D-code (Lebbe \& Oude Essinck, 1999) is applied to simulate the 3D density dependent groundwater flow. The modeled area is located in the breakthrough valley of the river Aa between the Flemish coastal plain and the Saint Omer basin. It is a rectangular area of $2000 \mathrm{~m}$ on $1620 \mathrm{~m}$. The finite-difference grid consists of 200 columns, 162 rows and 24 layers. All finite-difference cells have the same size. These cells have a thickness of $1.5 \mathrm{~m}$ and have a squared base plane with a side of $10 \mathrm{~m}$. The base of the uppermost layer is $15 \mathrm{mNGI}$. The uppermost nine layers consist of active and inactive cells. Due to the relative high topographic difference the number of the active cells in the uppermost layer is limited but these number increases in the downward direction. All cells of layers 10 to 24 are active. The northern, southern, eastern and western boundaries are impervious as well as the base of lowermost layer. In all uppermost active cells there is constant inflow of fresh water ( $\mathrm{Ps}=0.1 \%, 280 \mathrm{~mm} /$ year). All uppermost active cells are drained. The estimated drainage level is based on the topographic data. The dense network of drainage canals are considered as rivers in the model as well as the canalized Aa (le canal de Grand Gabarite).

Three hydrogeological units are considered: the quaternary marine sediments (QMS), the silt or the quaternary continental sediments (QCS) and the clay of Ypresian age (YC). Due to the lack of detailed maps of the heterogeneities of the QMS these sediments are simplified to a homogeneous anisotropic layer with a horizontal and vertical conductivity of respectively 2.5 and $0.04 \mathrm{~m} / \mathrm{d}$. The QCS and YC are less heterogeneous than the QMS. The assumed horizontal and vertical conductivity of the QCS are respectively equal to 0.04 and $0.002 \mathrm{~m} / \mathrm{d}$ whereas the assumed values for the YC are respectively 0.002 and $0.0001 \mathrm{~m} / \mathrm{d}$. The spatial variation of the transmissivities and hydraulic resistances between the finite-difference cells are derived with the aid of the topographic map and the map of the top of the YC. Two different simulations of the salinity distribution are made.

\section{Simulation 1}

The initial salinity distribution in the QMS is based on the estimated areal variation of the level of the interface between fresh and salt water. This areal variation is based on the application of the Ghyben-Herzberg relation (Todd, D.K., 1959) and the estimated average level of the watertable. The estimated watertable level is in its turn based on the topographic data. When the finite-difference cells with QMS are situated completely above the interface the initial salt water percentage (Ps) is set equal to zero. When these cells are situated completely below the interface the initial Ps $=100 \%$. When the salt-fresh water interface is located in a QMS cell the Ps is set equal to the percentage of the volume of the cell below this interface. The fresh water has a Ps $=0 \%$ and a TDS $\leq 800 \mathrm{mg} / \mathrm{l}$. The salt water has a Ps $=100 \%$ and a TDS $\geq 28 \mathrm{~g} / \mathrm{l}$. An initial Ps of $1 \%$ is attributed to the finite-difference cells which are situated in the QCS. The cells situated in the YC obtain an initial Ps of 5\%. The applied value for the water-conducting porosity is 0.38 . The longitudinal dispersivity is set equal to $0.3 \mathrm{~m}$ and the transversal dispersivity for horizontal and vertical flow are respectively equal to 0.05 and $0.03 \mathrm{~m}$. 
First, the evolution of the flow and salinity distribution is discussed by the aid of horizontal and vertical cross-sections. In these cross sections the fresh water head configurations are first shown between 1.75 and $17 \mathrm{mNGI}$, respectively the minimum and maximum value in the modeled area. With this representation it was not possible to show the small but important variation of the fresh water head in the valleys. Because these small variations in the fresh water head are important in the framework of the flow and salinity distribution in the valleys, the fresh water heads are represented between the interval of 1.75 and 2.35 mNGI (see Figure 3).

The flow and the salinity distribution in the central part of the valley and in the upper part of the QMS are similar as in the major part of the Flemish coastal plain (e. g. Vandenbohede \& Lebbe, 2000; Van Meir \& Lebbe, 2002 and Vandenbohede et al., 2004). There, the depth of the transition zone between fresh and salt water has a strong negative correlation with the average level of the watertable. A slightly higher watertable corresponds with a larger depth of the fresh/salt transition zone and vice versa. On the edges of the valley there is an inflow of fresh water from the elevated areas where QCS covers the YC. This inflow and the watertable which is slightly higher than in the central part of the valley, result in a deeper transition zone. In the upper part of the QMS the flow and the evolution of the salinity distribution are slow.

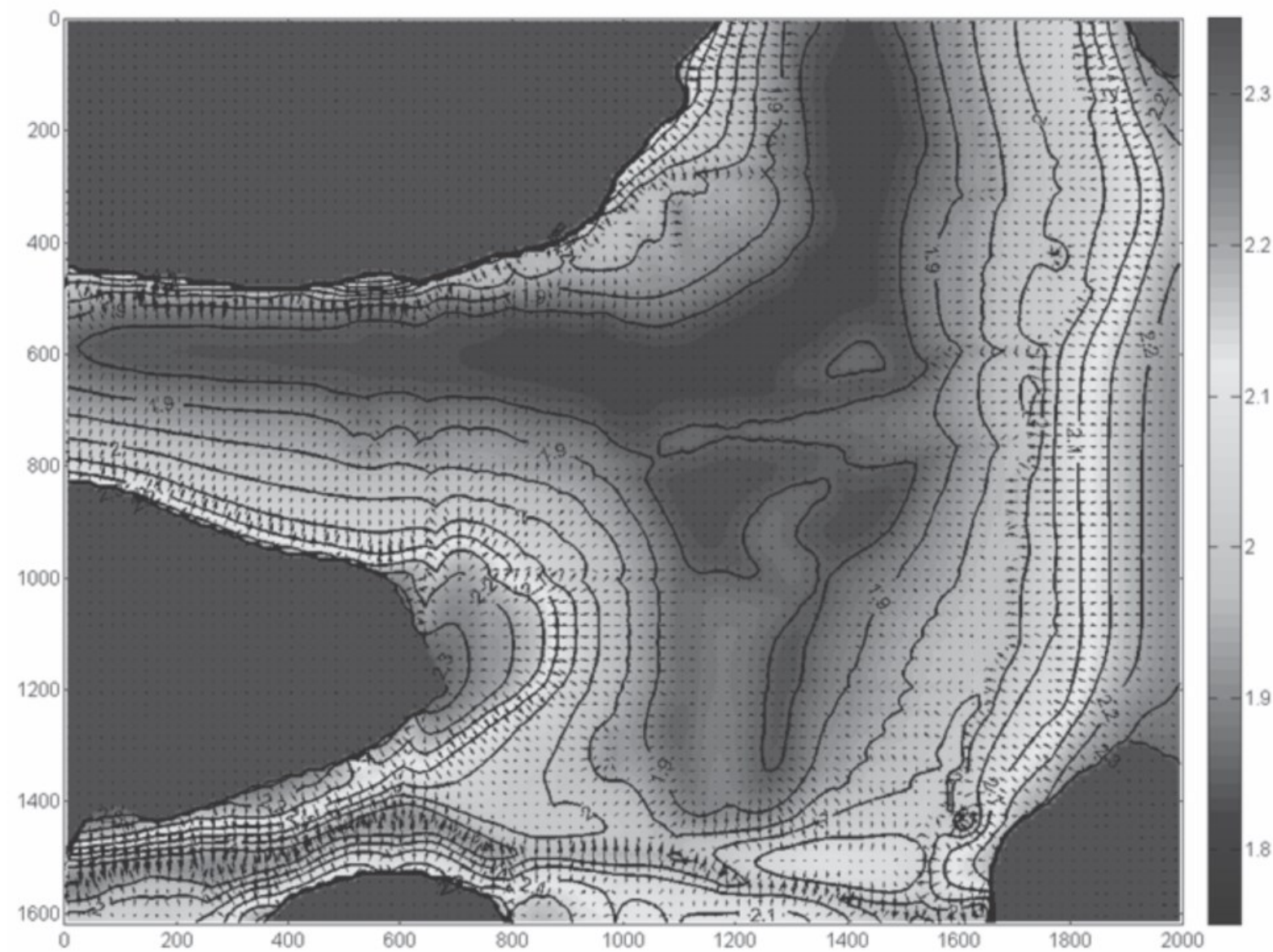

Figure 3. Fresh water head between the interval 1.75 -2.35 mNGI of layer 10 which is located between 1.5 and $3 \mathrm{mNGI}$ and horizontal groundwater flow vectors after 50 years (simulation 1). 
In the lower part of the QMS the flow after 50 years of simulation is considerably larger than in the upper part of the QMS. This flow is strongly dependent from the gradient of the top of the $\mathrm{YC}$ and of the initial salinity distribution which was estimated with the Ghyben-Herzberg relation. This flow results in a faster evolution of the salinity distribution in the lower part of the QMS. There occurs a flow of salt water to the QMS located in the deeper incision in the YC. This is in contrast with former simulations of salinity distribution made in other parts of the Flemish coastal plain where, however, the top of the $\mathrm{YC}$ is rather flat and where the fresh/salt water transition zone is located far above this top. In these last cases the flow of salt water above the top of the YC is very limited.

\section{Simulation 2}

In the second simulation the QMS are initially completely filled with salt water $(\mathrm{Ps}=100 \%)$. The initial salt water percentage of the QCS and the YC is the same as in the first simulation, respectively equal to 1 and $5 \%$. The evolution of the salinity distribution is simulated for the same hydraulic and solute transport parameters and with the boundary conditions for a period of 800 years, the estimated time since the last marine influence in the studied area. The evolution of the flow and salinity distribution is discussed and compared with the first simulation. At the end of both simulations the salinity distribution in the lower part of the QMS are similar. In the upper part of the QMS the salt water content is smaller at the end of simulation 1 in comparison to simulation 2 . This is due to the fact that the freshening process of the QMS lasted over a longer time period during simulation 1.

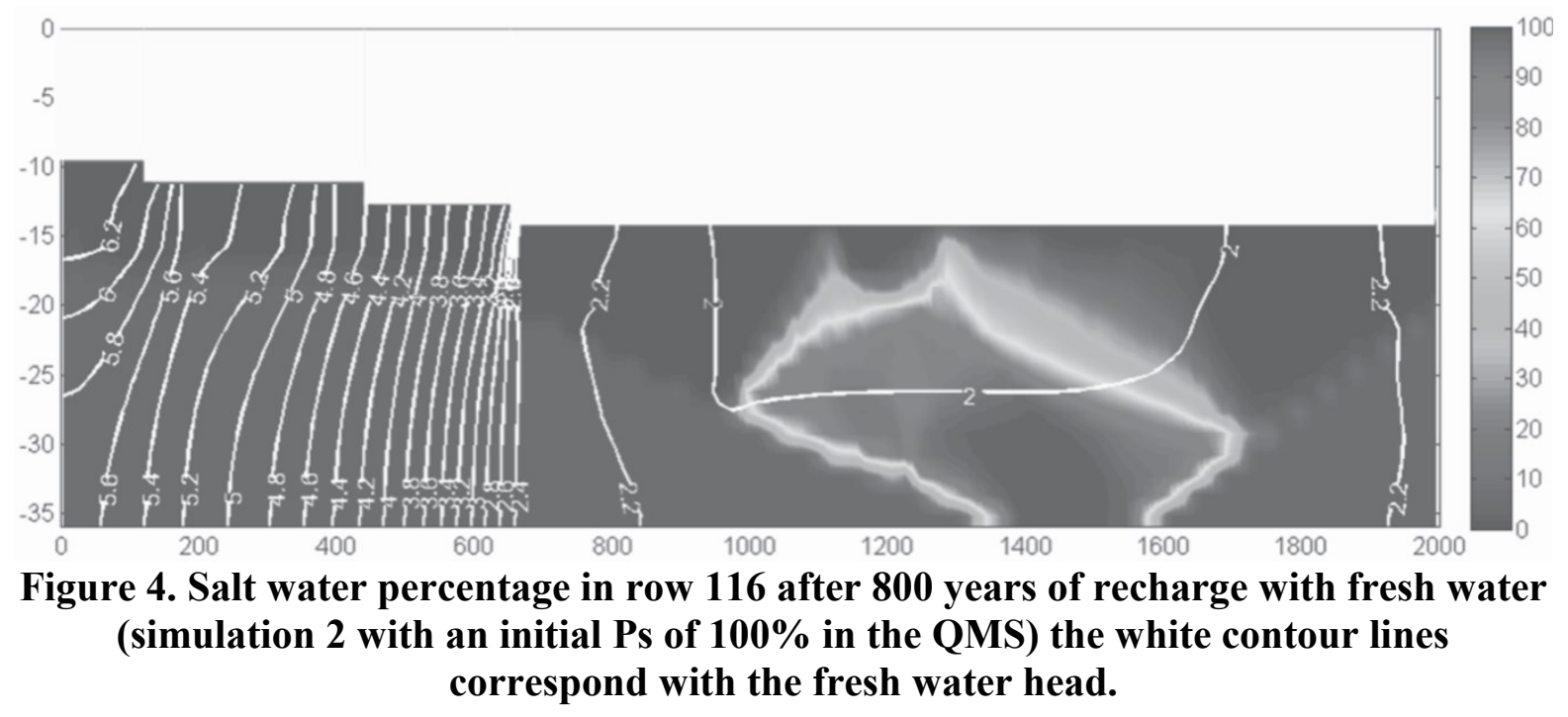

As a conclusion one can state that the salinity distribution in the QMS depends not only on the lateral variation of watertable but also on the shape of the incision of the palaeo-valley into the YC. The salinity distribution in the upper part of the QMS depends first and foremost on the lateral variation of the watertable whereas the salinity distribution in the lower part of the QMS depends first and foremost on the shape of the incision of the palaeovalley into the YC. In this studied case the Ghyben-Herzberg relation was not appropriate for the estimation of the initial salinity distribution in the lower part of the QMS. 


\section{DISCUSSION AND CONCLUSIONS}

In the breakthrough valley of the river Aa between the Saint Omer Basin and the Flemish coastal plain occurs a salt water intrusion. This salt water intrusion was studied by the aid of field observations and numerical model simulations. A limited number of observations wells allow the collection of diverse data to compare with the results of the numerical model such as the fresh water head, the variation of electrical conductivity of the deposits around the wells and the execution of a pumping test. The measured variation of the electrical conductivity of the water in the drainage canals furnishes valuable data to assess the evolution of the salinity distribution. The results of the simulations show that the evolution of the salinity distribution in the studied area depends also on the shape of the incision of the palaeo-valley into the clay of Ypresian age. This shape influences this evolution in addition to other characteristics of which the foremost is the lateral variation of the watertable. In the studied case the present day salinity distribution was not obtained after a relative short simulation period (e.g. 50 years) with an initial salinity distribution which was obtained by the aid of the Ghyben-Herzberg relation and the lateral variation of the watertable. This last mentioned method was, however, successful in other areas of the Flemish coastal plain where the top of the clay of Ypresian age is rather flat and where the fresh/salt water transition zone is located above this top. In the studied case where the top of the clay of Ypresian age has steep slopes there is a better method which, however, requested more computer time. In this method the simulation starts with the quaternary marine sediments completely filled with salt water and for a simulation time since the last marine influence in the area.

\section{REFERENCES}

Lebbe L. and Oude Essink, G. 1999. MOC DENSITY / MOCDENS3D-code. p. 434-439, in Chapter 12. Survey of Computer codes and Case Histories. Eds. Sorek, S. \& Pinder, G.F. in: Seawater Intrusion in Coastal Aquifers, Concepts, Methods and Practices. Eds. Bear, J., Cheng, H-D, Herrera, I., Sorek, S. and Ouazar D. Kluwers Academic Publishers.

Todd, D. K., 1959. Ground Water Hydrology, New York, John Wiley \& Sons. 336 p.

Vandenbohede, A. \& Lebbe, L. (2000). Water quality distribution in the eastern coastal plain of Belgium: Influence of intercalated peat beds. Proc. 16th Salt Water Intrusion Meeting, Miedzyzdroye, Poland, p.133-140.

Vandenbohede, A., Linster, T. \& Lebbe, L. (2004). Modelling of density dependent groundwater flow in the south-western Belgian coastal plain. Proc. of the 18th Salt Water Intrusion Meeting, 31 May-03 June 2004, Cartagena, Spain, 207-214.

Van Meir, N. \& Lebbe, L. (2002). 3D-density-dependent modeling of sea-level rise scenarios around De Haan (Belgium). Proc. $17^{\text {th }}$ Salt Water Intrusion Meeting, Delft, The Netherlands, p.73-81.

Contact Information: L. Lebbe, Ghent University, Faculty of Science, Geology Department, Krijgslaan 281 (S8), B 9000 Gent , Belgium, Phone: +32-9-2644653, Email: luc.lebbe@ugent.be 